\title{
A Post-Truth Proactionary Look at the Pandemic
}

\section{Steve Fuller ${ }^{1}$}

Published online: 20 April 2020

(C) Springer Nature Switzerland AG 2020

\section{Quantum Epistemology in Action}

When the Covid-19 crisis was about to send my university into lockdown in midMarch 2020, I sent a message to all my students about how they might think about the crisis (Fuller 2020). I stressed the anchoring effect of how the crisis first received worldwide attention. An overstretched doctor working in an intensive care unit at a hospital in Wuhan, China, panicked at the rate of patient intake and their rate of deathand did so on social media. The social media part was the truly new development, arguably more novel than the coronavirus itself. After all, viruses mutate all the time and can even pass between species, and air pollution in Wuhan - like other big Chinese cities - had long been a breeding ground for the viruses that cause respiratory ailments. Indeed, it is an ecological legacy that has been felt in the waves of more or less lethal forms of 'influenza' worldwide that have beset the entire industrial era.

In the first instance, influenza tests the capacity of health care systems, and in the past, most have struggled and many have failed to cope - but without raising the alarm at the global level to such an extent that capitalism was brought to its knees, as it has been by Covid-19. After all, it is not every day that the Financial Times (2020) calls for a 'Welfare State 2.0' on a scale that 75 years ago led to the establishment of the United Nations. Because flu viruses typically feed on existing vulnerabilities in a patient's condition, hospitals would typically need to register a higher than expected morbidity rate before a new virus was detected. But of course, previously the world's health care systems were not being exposed simultaneously for all to see on social media. As the capacity for a virus to go 'viral' increases, sensitivity to the virus' presence increases, which in turn reduces the time before an 'epidemic' and then a 'pandemic' is declared, which serves to accelerate the comprehensiveness with which measures are taken to fight the virus. Moreover, and importantly, intensified scientific scrutiny on the virus also generates backpropagation effects, effectively a rewriting of medical history whereby earlier data is reclassified so that a greater number of people - both living and deceased - are revealed to have contracted the virus.

Steve Fuller

s.w.fuller@warwick.ac.uk

1 University of Warwick, Coventry, UK 
What I have just described is the outworking of a quantum epistemology, whereby ailments and deaths that would have been diagnosed as extreme instances of the default disease categories are 'converted' - as in a Gestalt switch — so as to be directly attributed, both in retrospect and in prospect, to Covid-19 through the 'observer effect' of the intensified medical gaze (Fuller 2018: chap. 6). In short: the more we look for Covid-19, the more likely we are to find it. What had been non-existent is now and always is everywhere. A similar observer effect will occur once the pandemic's conclusion is formally declared by the World Health Organization, and we properly enter the 'lessons to be learned' phase. There will undoubtedly be a reversal of fate for at least some policies that are currently being hailed or condemned, once the final toll has been taken. (I write this in early April 2020.) Indeed, the run-up to this second moment is marked by the sort of competitive expectation management that we normally see when 'bull' and 'bear' analysts try to forecast the stock market. Each wants to be the first to declare how things will have always been.

\section{How Many Deaths Make a Good Outcome?}

For example, based on the model used to guide the UK's Covid-19 strategy, the nation's Chief Scientific Advisor Patrick Vallance told a Parliamentary Select Committee at the start of the pandemic that 20,000 British deaths would be a 'good outcome'. At the same time, others have written post-mortems on the UK strategy before all the bodies have been counted. The critics often make life easy for themselves by denying at once the validity of the target and the government's strategy to reach ittypically by pointing to the example of Germany, which is expected to have many fewer deaths. So even if Vallance's 'good outcome' is met, the critics might still claim victory - and indeed, accuse the UK government of having 'cynically' set its expectations low. An interesting epistemological difference between the government and its critics is that the government stresses that if a particular nation's Covid-19 strategy ends up appearing to have been successful, it will have been due to a combination of factors specific to that nation, whereas the critics stress that, say, Germany already possesses the all-purpose 'magic bullet' - mass testing of the population - that nations everywhere should have deployed to conquer the virus. We might think of this difference as a matter of 'anticipatory diagnosis'.

At a more general level, the market in expectation management is emblematic of the post-truth condition (Fuller 2018: chap. 2). At stake ultimately is not which nations tackle the virus most effectively but the terms on which 'effectiveness' is decided. If the virus is the opponent in a match against humanity, the main question is not who wins but who gets to name the game being played. It is a 'second order', not 'first order', problem, as the logicians say. This explains why the UK cannot simply get away with setting its own targets, even it meets them. Moreover, one can envisage 'third-order' terms in which to deal with Covid-19. So let us imagine that the current fight against the virus is 'completed', at least in the sense that the spread of Covid-19 is 'contained'. This opens a market in which some are 'projecting' (i.e. both assuming and promoting) that 'we' (i.e. most of us) have won and others are projecting that we have lost. The former want to resume business as usual as quickly possible, while the latter want to take the radically changed circumstances as an opportunity to play a different game. 
That is the third-order game against the virus, on the cusp of which sits the Financial Times editorial mentioned earlier.

The editorial cites the United Nations as a precedent for a post-pandemic world order, but its history displays the ambiguous field of play in the third-order game. Much of the organization's early rhetoric portrayed it as a proper world government that would establish human solidarity on a new footing, one that transcended the modern system of nation-states, known in international relations circles as the 'Westphalian Order'. Thus, the UN Universal Declaration of Human Rights alluded to the unprecedented horrors - 'crimes against humanity' - unleashed by the Second World War as the pretext for the UN Charter. Indeed, the very idea of 'human rights' with juridical standing pointed to the insufficiency of 'civil rights' inscribed in national constitutions. No more business as usual! Unfortunately, the Charter's details reveal that the UN's powers are no more than what its constituent nation-states are willing to delegate to it. The UN has no independent authority to be a proper rival to the nation-states themselves, and over the years, it has best lived up to its early rhetorical promise when dealing with failed states and failed inter-state relations. In effect, the UN is little more than the Westphalian Order's insurer of last resort: It has maintained business as usual.

What I have recounted may sound like a sorry tale. However, it is worth recalling that 'business as usual' is also the spirit in which national governments have bailed out banks following global financial crashes from the Great Depression onward. To be sure, it has been in terms of the confident rhetoric of building 'robustness' and 'resilience' into the system - but we are still talking about the same system that generated the crisis in the first place. Nevertheless, those who have wished to turn the latest global crisis into an opportunity for radical change - from Marxists to environmentalists - have been historically hamstrung by such rhetoric. In the 1930s, radical socialists were dealt a sharp and arguably irreversible blow by the speed with which Franklin Roosevelt proposed and enacted 'New Deal' legislation, whereby the emerging superpower showed the world the way back to business as usual in the capitalist world order. It is not unreasonable to look to the current emerging superpower, China, for guidance back to a post-pandemic business as usual - especially since, like China today, the USA had practiced a notoriously protectionist international trade policy in the years prior to the Great Depression.

But the alternative version of the third-order game has not gone away. Its 'no more business as usual' attitude is predicated on our having lost the fight against the virus. However, this may not be as bad as it first seems because we are imagining this prospect, rather than having experienced it. That cognitive difference can effectively immunize us from the worst effects of the virus - or, indeed, any existential threat. At least that was how the great US Cold War strategist Herman Kahn (1962) thought about 'the unthinkable', namely, a thermonuclear war. Kahn estimated that the realistically worst outcome of a nuclear confrontation between the USA and USSR would kill no more than a third of the human population. And without denying such a tragic loss of life at an unprecedented scale, his strategic focus was on how the survivors might coordinate their activities to rebuild civilization. After all, the existing communication infrastructure would be among the most vulnerable targets of such an all-out war. This was the context in which the Internet was developed by the US Defence Advanced Research Projects Agency (DARPA) in the late 1960s. Of course, the imagined war never happened, but the Internet was rolled out anyway - and became the platform on which the 'third industrial revolution' was launched (Rifkin 2011). 


\section{Never Let a Good Existential Threat Go to Waste}

I have characterised this sort of third-order response as 'moral entrepreneurship', in the spirit of Obama Chief of Staff Rahm Emanuel's notorious offhand comment, 'Never let a good crisis go to waste' (Fuller 2012: chap. 4). More generally, its attitude to risk is not precautionary but proactionary - which is to say, it capitalises on the nature of uncertainty to convert potential threats into opportunities (Fuller and Lipinska 2014). As Franklin Roosevelt put it in his 1933 inaugural presidential address, '[t]here is nothing to fear but fear itself'. However, the sensibility goes back to Baron Helmuth von Moltke's successful revision of strategic thinking during the 1870-1871 FrancoPrussian War. Moltke effectively raised the stakes of warfare from limited objectives to national security itself, always with an eye to the next war-and there will be a next war, perhaps against some radically different opponent, even if one wins the current war against the known opponent. Moltke's vision was one of endless 'total war', which required the nation to be in a state of 'permanent emergency' to ensure that, whatever the outcome of any particular war, the nation is never defeated 'once and for all' but can always 'rise again' (Fuller 2000: 105).

Kahn and other Cold War strategists adopted Moltke with gusto, resulting in a raft of new sciences and technologies - as in the Franco-Prussian War, when epidemiology came into its own as a science, with Louis Pasteur and Robert Koch spearheading their respective national biomedical efforts (Fuller 2018: chap. 4). Philip Tetlock's concept of superforecasting, which duly acknowledges Moltke, is the latter-day incarnation of this mentality (Tetlock and Gardner 2015: chap. 10; Fuller 2018: chap. 7). But perhaps most consequential of all is what might be seen as a 'fourth-order' effect of the original fight against the virus. It came to be associated with Moltke's civilian commander, Otto von Bismarck, who turned the Second German Reich into the first modern welfare state - what the US sociologist Alvin Gouldner (1970) pointedly called at the height of the Cold War 80 years later, the 'welfare-warfare state'. Bismarck fully conceptualised the nation-state as an organism perpetually struggling for survival in a potentially hostile environment. Protection literally meant education and health coverage to keep everyone 'fighting fit' to contribute to economic productivity in peacetime and military might in wartime. Its modus operandi included taxation and conscription.

But Bismarck did more than that. His specific 'fourth order' genius lay in analogically extending the idea of 'potential external foes' to include radical new ideologies, such as Marxism, which had already threatened to undermine the nascent welfare state by portraying it as an engine for generating an endlessly exploitable population. Bismarck's solution was to introduce retirement pensions, showing that people were valued even when they were not directly contributing to national security. This resulted in a comprehensive 'social security' system, which extended beyond the borders of the nation-state to its constituent human members. In terms of the Realpolitik of which Bismarck was the master, this policy neutralized many Marxists who ended up normalizing themselves as the Social Democratic Party, which became the largest party in the Reichstag and even supportive of Germany's ill-fated involvement in the First World War. Political sociologists recall this episode as the paradigm case of co-option, the body politics' way of establishing equilibrium with a potentially lethal enemy by incorporating it as a kind of 'natural vaccination' (Michels 1911/1959). In effect, Germany achieved 'herd immunity' with regard to radical left-wing politics, 
notwithstanding Marx's own prediction that due to its large organized labour movement, the proletarian revolution should first happen there.

In conclusion, let me underscore why the intellectual trajectory I have been outlining to navigate through the Covid-19 crisis is 'proactionary' rather than 'precautionary'. Adherents to the precautionary principle tend to presume that humanity is 'always already' subordinated by some generic external agent called, say, 'Nature' or 'Gaia', in terms of which we might be either in equilibrium or in conflict. In either case, that opponent is not subject to negotiation: It poses an ultimate limit of permissible activity. In contrast, adherents to the proactionary principle tend to presume a more game-like relationship to the opponent, whereby Nietzsche's Zarathustrian imperative, 'What doesn't kill me, makes me stronger', really does apply. This suits the world of endless pandemics, in which the opponent may be contained for now but may mutate to pose a future threat, which in turn may require a radical revision of one's modus operandi and even raison d'etre - including incorporation of the 'other' previously not seen. After all, we should never let a good existential threat go to waste.

\section{References}

Financial Times (2020). Virus lays bare the frailty of the social contract. Financial Times, 3 April. https://www. ft.com/content/7eff769a-74dd-11ea-95fe-fcd274e920ca. Accessed 13 April 2020.

Fuller, S. (2000). Thomas Kuhn: A philosophical history for our times. Chicago: University of Chicago Press. Fuller, S. (2012). Preparing for life in humanity 2.0. London: Palgrave Macmillan.

Fuller, S. (2018). Post truth: Knowledge as a power game. London: Anthem.

Fuller, S. (2020). 'When a virus goes viral: Life with COVID-19'. Social Epistemology Review and Reply Collective, 17 March. https://social-epistemology.com/2020/03/17/when-a-virus-goes-viral-life-withcovid-19-steve-fuller/. Accessed 13 April 2020.

Fuller, S., \& Lipinska, V. (2014). The proactionary imperative. London: Palgrave Macmillan.

Gouldner, A. (1970). The coming crisis in Western sociology. New York: Basic Books.

Kahn, H. (1962). Thinking about the unthinkable. New York: Horizons Press.

Michels, R. (1911/1959). Political parties. New York: Dover Books.

Rifkin, J. (2011). The third industrial revolution: How lateral power is transforming energy, the economy, and the world. New York: Palgrave Macmillan.

Tetlock, P., \& Gardner, D. (2015). Superforecasting: The art and science and prediction. New York: Crown Publishers. 